\title{
Cooperative Relations in Agricultural
} Development

Address of E. T. Meredith, Secretary of Agriculture Before the Land-Grant College Association Springfield, Mass., October 20, 1920

UNITED STATES DEPARTMENT OF AGRICULTURE CIRCULAR 153 OFFICE OF THE SECRETARY 
Published in response to a request of the Land-Grant College Association, October 20, 1920

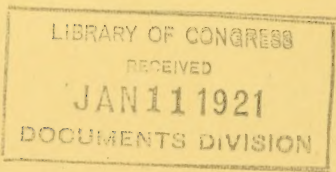

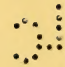




\section{COOPERATIVE RELATIONS IN AGRICULTURAL DEVELOPMENT.}

THIS, in a real sense, is a family gathering. The insti-
tutions we represent are dedicated to public serv-
ice, and we are seeking in many of our activities to
attain a common object-the strengthening of our national foundations by the upbuilding of our great basic industry. I take it, therefore, that we may discuss our mutual problems with the candor that should characterize the interchange of views among members of the same household; and I know you will believe me when I say that I count it a privilege and an honor to appear before this association, which includes in its membership the men who to-day are shaping the destiny of agriculture, men who must play such an important rôle in meeting some of the increasingly difficult and complex problems confronting us at this time and those which will arise in the years that lie immediately ahead.

I shall not attempt to indicate to this body what these problems are or are likely to be. It would be presumptuous for me to do so. There are men here to-day who are far better qualified than I am to deal with such questions in a comprehensive way, and we must look to them for advice and guidance. I do wish, however, to discuss with you some matters of mutual concern to the land-grant colleges and experiment stations and to the Department of Agriculture.

The Department of Agriculture was brought into being 58 years ago. Two years later the land-grant colleges were established. For more than 20 years these great agencies worked together for the betterment of 
agriculture before there came into existence the agricultural experiment stations; and these three sets of institutions have made contributions of untold value to the science and practice of agriculture. They have cooperated, and are cooperating, with each other in innumerable ways, but there still exist many opportunities for the further development of our cooperative relations. In a few cases, and I am happy to say that they are very few, the colleges and the department have been pulling at cross-purposes not because the ends they wish to attain are different, but because they do not thoroughly understand one another and are using different methods - with resulting lost motion that could probably be avoided by closer contact and understanding.

\section{CLOSER COOPERATION NECESSARY.}

I am anxious to do everything in my power, while I am in the Department of Agriculture, to aid in promoting the more effective coordination of efforis among our agricultural agencies within their respective fields. Much has been done along this line within the past few years, but much remains to be done. Cooperation is a word that is very much in vogue these days, but, generally speaking, I think its true meaning is little understood. Certainly there can be no thoroughgoing cooperation unless there is a real desire to cooperate, and, it seems to me, that both the colleges and the department should overlook no opportunity to develop such a spirit - a desire to cooperate-among their workers. No matter bow many agreements we enter into, their purposes can not be fully realized unless this spirit is fully developed, unless there exists between the parties to them a genuine feeling of mutual confidence and good will and an earnest desire and willingness to be helpful to each other. Your association, through its appropriate committee, recently suggested the desirability of appointing an officer in the department whose specific duty it would be to promote better relations and closer 
coordination of work between the colleges and stations and the department. I have accepted this recommendation in the spirit in which it was made, and I am convinced that its adoption would be mutually beneficial to all these agencies. I have, therefore, recommended in our estimates for the next fiscal year, which have just been submitted to the Congress, that authority be given to appoint a director of scientific work, at a salary of $\$ 7,500$ per annum, who shall be a permanent officer and who will devote his attention not only to the development and coordination of the research activities of the various branches of the department but who will also work out and put into execution plans for the further correlation of these activities with those of the appropriate State agricultural agencies. I may add that I have also asked Congress for authority to appoint a director of regulatory work who will function in essentially the same way with reference to the regulatory work of the department.

\section{MUST GIVE MORE THOUGHT TO RESEARCH.}

I do not need to remind you gentlemen of the basic importance of research - and I use the word in its most comprehensive sense. It is the foundation of agricultural progress. Without it many of our agricultural activities could not exist under present conditions and others would be seriously crippled. All our most important problems along control lines are based on years of patient research. Swine production in a large way is dependent upon hog-cholera control; the cattle industry upon tuberculosis eradication, and in the South upon cattle-tick eradication; the fruit industry upon scientific methods for the protection of both trees and fruit; many field and truck crops upon methods of disease control, the introduction and development of new varieties, and the working out of improved cultural methods and practices.

I might go through the entire range of agriculture, giving illustrations of the application of the results of scientific study to everyday problems, but it is unneces- 
sary for me to do so here. Indeed, so much has been accomplished through the results of research that many people are dangerously near falling into the error of thinking that not much more work of this character is needed and that the requirements of the day relate merely to the application of knowledge already in hand. Research is more essential now than ever before, and the need does not relate wholly to the matter of taking care of the future. We are confronted to-day with serious problems of the most pressing nature about which we know very little. A striking instance is contagious abortion of cattle, a disease which handicaps the cattle industry of the country to an enormous degree. We have no successful method of combating it. Another is the breeding of domestic animals, which is still largely a matter of chance, and entirely too little fundamental research work upon it is in progress. No one will deny, I am sure, that it would be the part of wisdom to concentrate the best brains of the country on this important problem and to provide adequate facilities for carrying on the work in the most comprehensive manner. Still another problem about which we know relatively little is that of the control of animal parasites. In large areas of the United States they constitute perhaps the greatest limiting factors in animal production. In every section they are problems of importance. I am told that there are probably 40 different parasites, about many of which we have little exact knowledge, that affect hogs alone. To acquire the needed information and to work out proper methods of preventing or controlling these pests a great deal of research of the highest order is necessary.

\section{MUST FACE SITUATION FRANKLY.}

There are numerous other problems of equal importance and urgency relating to the soil, to plant diseases, to plant breeding, and to all other phases of agricultural production.

We must be frank enough with ourselves to recognize the fact that fundamental research has not gone forward 
as rapidly as our best interests demand, and it seems to me that the time has come for us the colleges and stations and the department-to see that it is given and retains the proper place in our respective organizations. I am sure that nowhere has the importance of research been consciously minimized, but, in the exigencies of war and its aftermath, a situation has come about which, I think you will agree, amounts to neglect of this basis of agricultural progress. The rapid growth of extension work, the value of which I fully appreciate, has contributed to this result. We have been so busy with extension, so amazed also at the rapidity of its growth and application, that we have not found time to give to research, during the past few years, the careful planning and deep thought that it should receive. Unless we are to permit an insidious undermining of the whole structure that we have reared through six decades of tireless work, we must have a larger number of thoroughly trained and experienced investigators to give their time exclusively to research. Upon the agricultural colleges rests the responsibility of training the agricultural leaders and investigators of the future; they must provide the men and women needed by the experiment stations and the Department of Agriculture for the prosecution of their activities. There is a community of interest, therefore, among these three agencies in dealing with this great problem and in seeing to it that there is constantly available an increasing number. of well-trained and thoroughly grounded men and. women to carry on the work intrusted to them.

\section{NEW SET OF PROBLEMS TO SOLVE.}

There are many lines of research which are relatively undeveloped and to which, it seems to me, the department and the colleges in cooperation should give more attention in the future. I have in mind especially the study of the economic problems involved in marketing and distribution, in farm management, in land utilization and settlement, and in cooperative effort among farmers for various purposes. Until a few years ago 
relatively little systematic work had been done to aid in the solution of the complex problems arising in connection with the distribution of farm products. Now the Bureau of Markets of the Department of Agriculture is actively at work in this field, and many of the land-grant colleges, to which the bureau must necessarily look in recruiting its personnel, have established courses in marketing, but I imagine some of these courses could be strengthened and that others could be developed. The activities of the Office of Farm Management and Farm Economics have, within the past two years, been redirected and expanded so that it is now in position to deal more effectively than ever before with broad economic problems, including farm management, land settlement and utilization, and the like; and here again the department must depend upon the colleges to provide the necessary number of trained men.

Another line of werk that could well be enlarged is that relating to the development of processes for converting perishable farm products into commodities sufficiently staple to be carried from the season of plenty to the period when they are actually needed. The fact that they can net now be so carried results in the marketing at one time of larger quantities than can be disposed of profitably and demoralization of the market follows, with consequent loss to the farmers. Industries founded upon the utilization of farm products in seascns of excess are of tremendous permanent value. As an illustration, I may cite the investigations conducted by the Bureau of Chemistry looking toward the development of a citrus by-products industry for the utilization of cull and surplus oranges and lemons. The effort of the bureau to aid in the establishment of a dehydration industry is another instance. Still another is the task of developing technological processes for preserving perishable food products. This is illustrated in the studies of the Bureau of Markets and the Bureau of Plant Industry in the preservation of fruits and vegetables and of the Bureau of Chemistry in methods of 
packing, shipping, and storing poultry and eggs. Then there is the problem of providing outlets for waste products, of which the utilization of corncobs for the making of adhesives, cellulose, furfural, and other valuable products is a striking example.

\section{BETTER ENGINEERING COURSES NEEDED.}

Much remains to be done, also, in developing the field of rural engineering. This is one of the newer branches in the department and in the colleges, and a number of the latter, I believe, have not yet instituted courses for the training of men along these lines. Some of the large problems with which the farmers have to deal are engineering in character. No uniformity now exists in the rating of farm machines, such as silage cutters and blowers, pumps, and other farm equipment. Comprehensive tests have not been made of farm power, either mechanical or animal. The Bureau of Public Roads proposes to inaugurate a comprehensive study of mechanical power on the farm, in cooperation with the agricultural engineers of the State colleges, and the problems relating to farm buildings, heating, lighting, ventilation, and the like should be studied in the same manner.

The colleges can perhaps do more than any other agency to bring about a better recognition of forestry as an essential part of agricultural science. The depletion of our timber supplies has reached such a stage as to make it incumbent upon both the colleges and the department to begin a definite and earnest effort to solve the problems of timber production on the farms. A beginning already has been made along this line in a few States and I hope that others will turn their attention to it in the near future. I may add that the department is planning to ask Congress for an increased appropriation to further a national program of forestry and, if it is granted, it will be in position to prosecute the farm forestry project vigorously in cooperation with the colleges. 
MUST TRAIN MEN IN METEOROLOGY.

Practically nothing is being done, outside of the Weather Bureau of the department, toward the development of meteorology as a science. Less than half a dozen institutions in the United States have definite courses in meteorology, and these are inadequate to meet the requirements. As a matter of fact, few students have expressed a desire to pursue courses of this character because opportunities for employment in meteorological work have been confined almost entirely to the Weather Bureau. Recently there has been an increased interest in meteorology resulting from the unprecedented development of aviation and aeronautics, and more attention is being given than ever before to the utilization of meteorological data in connection with commercial and agricultural activities. The time is fast approaching when there will be many opportunities for the employment of highly trained meteorologists in many lines of industry, and the development by some of the land-grant colleges of adequate courses in this branch of science is worthy of consideration.

There are still large problems unsolved in connection with the extension work. The county-agent system is not complete. At least 600 counties need county agricultural agents; about 1,800 counties have no home demonstration agents, and only a small fraction of the farm boys and girls are being reached by the club movement. The great need at the present time is for well-trained men who can carry on this highly useful and immensely important work, and the land-grant colleges, of course, are the proper agencies to train them. The rapid growth of the farm bureau movement and the increasing interest among farmers in the economic problems of agriculture, especially in marketing and transportation, has led to a situation in which the educational value of extension work is likely to be endangered by monopolizing the time and energy of the county agent in purely commercial transactions. We must study this problem with the view of working out policies under which the needs of the farmers in cooperative marketing and other 
business affairs may be met without impairing the educational feature of the extension work.

FULLER INFORMATION FOR FARMIRS.

This leads me to suggest that more attention should be given, both by the department and the colleges, to the furnishing of information to farmers, through the exlension service and in other ways, regarding the supply of agricultural commodities not only in the hands of agencies in this country but also those available in other sections of the world. This information should be presented in such a way as to show elearly to the average farmer the probable effect that existing supplies will have on future prices; and, in connection with the development of processes for utilization of surplus products, it would be a great aid to them in regulating their planting and markeling operations so as foreduce many of the losses they are now compelled to suffer. It is not my thought that the colleges and the department should undertake to advise farmers specifically what they should or should not produce during any season, but rather that they should place the facts before the farmers in such a way that any inteligent farmer might decide for himself what he should do.

When all is said and done, neither the colleges nor the department can render the most effective service unless they have an adequate, well-trained persomnel, and the problem of securing and maintaining such a persomel is of mutual concern. If we are to discharge our responsibilities to the public, we must see to it that the salary standards and opportunities, both of the colleges and the department, are such as to attract and hold the ablest and most far-seeing scientific men in America. The turnover in the department, especially among the research workers, has reached an alarming stage and we are threatened with a serious disintegration of the service. I assume that the colleges are confronted with essentially the same situation. Unless something is done to remedy existing conditions we can not hope to maintain the integrity of our research and other activi- 
ties. Valuable men are leaving us constantly for salaries two, three, four, and even five times as much as we are able to pay them. It is not to be hoped, of course, that we can ever meet that kind of competition, and, in fact, our scientific men do not expect it. As a general rule they do not feel that we should pay them as large salaries as they could secure in private employment, but they do feel-and I am in full sympathy with their view-that they should reecive compensation sufficient to enable them to keep themselves and their families in reasonable comfort. Unless we can pay them more adequate compensation our institutions will continue to be drained of many of their most efficient worker's, and in time a serious, almost a fatal, blow will have been struck at the root of agricultural progress, because much of the work done by the Department of Agriculture, by the agricultural colleges, by the agricultural-extension agencies of every kind, rests, in the final analysis, on the results obtained by the research workers.

\section{SCIENTISTS MUST HAVE BETTER SALARIES.}

It is of the utmost importance that the colleges and the department should be in position to retain their scientific workers over long periods. From the standpoint of public service, a man once embarked in an important field of investigation, if he is capable and efficient, should remain there for the rest of his active career. If he leaves to accept other employment, he carries with him much of the information he has secured in the progress of his work which enriches him in experience but which can not possibly be put on record. This means, of course, that a new man continuing the problem must, in many instances, go over a considerable part of the field already covered before he reaches the point where his predecessor left off. In dealing with this vital problem of personnel there are many ways in which the colleges and the department can cooperate to mutual advantage, and it behooves us to do everything in our power to see that the present situation is remedied, and remedied promptly. 
Our inability to pay adequate compensation to our scientific workers is due to the lack of sufficient funds, or to limitations placed on the discretion of executive officers by Congress or the legislatures of the various States, and these, in turn, are due in large measure to the lack of understanding on the part of the public of the importance of research work. The only way, or at least one way, by which this situation can be corrected is for the colleges and the department to combine in an eflort to outline the great and pressing problems in the field of agriculture and to emphasize the importance of their solution so that the cooperation of all the people of the country may be secured.

\section{CULTIVATE PUB!,IC OPINION.}

It seems to me that, on the whole, we have given too little attention to public opinion as it relates to agricultural problems. Any misconception on the part of a large group of individuals as to the true function of public institutions relating to agriculture is almost certain to retard progress. Generally speaking, the consumer thinks that agricullumal institulions. including the colleges and the department, are maintained for the benefit of the farmer and for his benefit alone. 'This. of course, is not true. These institutions are serving. with a high measure of efficiency, the whole people. urban as well as rural. During the past 50 years the relative decrease in agricultural population and the increase in urban population has been very marked. Yel. on the whole, the smaller pereenlage of persons engaged in agriculture has produced adequate supplies of farm products. Inereased eflicieney directly altributable to the work of agricultural institutions has ecrlainly played an important part in bringing aboul this result. Everything done by them that has helped to increase production and to eliminate wastes not only has added to the farmer's income but has also benefited the eity consumer. This fact, however, is not generally understood. One of the tasks ahead of us is to see that such an understanding is conveyed to the public; that it is 
demonstrated to the people in the cities, as well as those in the rural districts, that the funds devoted to agriculture are not used in the interest of the farmer alone but in the interest of the consumer as well.

The means for accomplishing this end ought to be carefully considered and then put into operation as promptly as possible. We should overlook no opportunity to present agricultural problems in the most attractive and effective way to city organizations, such as boards of trade, chambers of commerce, community associations, the press, and others. Emphasis should be placed on the dependence of the city man on the agricultural community, both as a source of food supply and as a market for manufactured products, on the fact that farming, if it is to continue to meet the Nation's requirements, must provide an adequate return to those engaged in it, and on the necessity of making country life more attractive. We should emphasize, too, the common interest of the farmer and the city man in such problems as those of providing a sufficient farm labor supply, adequate transportation facilities, and ample finance for agricultural needs.

\section{PROFIT BY LESSONS OF IVAR.}

In closing, I wish to emphasize again my earnest desire to do everything in my power to promote closer and more effective cooperation belween the department and the colleges. The war taught us the value of cooperation and we should not fail to take, full advantage of the lesson we have learned at such great cost. We all know the part that science played in the winning of the war, and that it was not until the scientific men of the allied countries united in solving the complex technical problems of warfare that victory was assured. Lack of cooperation between the agricultural agencies of the Nation would, I believe, be prevented or obviated by better knowledge on the part of each organization of the aims and viewpoints of the others. The appointment of a director of scientific work in the department will, I am sure, do much to bring about closer relations, and it 
occurs to me also that a system for the exchange of scientific workers is worthy of consideration. By this I mean that it might be feasible to develop a plan whereby men working along special lines in the various branches of the department might be exchanged, in limited number for limited periods, with scientists working along similar lines, either as research men or as teachers in the colleges. In this way the department's methods of work and of handling problems would be carried to the colleges and their methods of work and their way of considering and dealing with problems would be brought to the department, with benefit to both. Such a plan, it seems to me, would result in closer contacts and better understanding, and would lead to new ideas in both organizations relative to the important lines of research and other work to be undertaken.

For the department I wish to say that it is our hope and our desire that there may be strengthened wherever possible the close relationships now existing between us, hoping that we may be of increased service to you, and knowing that we will receive great help and inspiration from you in carrying forward together work for the development of agriculture, the basic industry of the country. 




\section{LIBRARY OF CONGRESS}

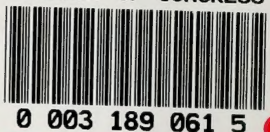

